\title{
SUBSTITUSI TEPUNG LABU KUNING (Cucurbita moschata Durch) DAN KORO PEDANG (Canavalia ensiformis L.) TERHADAP TERIGU PADA PEMBUATAN CAKE
}

Substitution of Wheat Flour with Pumpkin (Cucurbita moschata Durch) and Jack Bean (Canavalia ensiformis L.) Flour on Production of Cake

\author{
Pratiwi Loelianda $^{1)} *$, Ahmad Nafi ${ }^{1)}$, Wiwik Siti Windrati ${ }^{1)}$ \\ ${ }^{1)}$ Jurusan Teknologi Hasil Pertanian, Fakultas Teknologi Pertanian, Universitas Jember \\ Jalan Kalimantan 37, Kampus Tegal Boto Jember 68121 \\ *E-mail: pratiwiloelianda@gmail.com
}

\begin{abstract}
Cake is one of the products bakeries. The main ingredient on the production of cake is wheat. Until now, Indonesia still imports wheat from other countries. Thus, to reduce wheat consumption can use food diversification such as pumpkin and jack bean. Jack bean (Canavalia ensiformis L.) has protein and carbohydrate content $24 \%$ and $25 \%$ respectively. Pumpkin (Cucurbita moschata Durch) is one of the agricultural commodities has protein and carbohydrate content 1,1,\% and 6,6\% respectively. The purpose of this research are to know the effect of pumpkin and jack bean flour on the physic and organoleptic characteristic of cake, to know the best formulation of pumpkin and jack bean flour. The best treatment cake is P5 (50\% flour: 10\% yellow pumpkin flour: 40\% jack bean flour). Cake was ${ }^{0}$ hue at 92,20 which shows yellowish white color, chroma value at 22,26, expandability is 230,38\%, staleness of day 0 at $42,72 \%$, 4 change on day 0 tol by $1.96 \%, 4$ change on day 1 to 2 by $2.73 \%$, effectivity test at 0,54\%, Water content 38,26\%, ash content 0,96\%, fat content $4,01 \%$, protein content $28,28 \%$, and carbohydrate content $31,47 \%$.
\end{abstract}

Keywords: cake, pumpkin, jack bean

\section{PENDAHULUAN}

Cake merupakan salah satu produk bakery yang membutuhkan kandungan gluten untuk membentuk struktur cake, bahan utama pembuatan cake adalah terigu dengan kandungan protein sedang 10-11\%. Menurut data BPS Jawa Timur untuk perkembangan ekspor dan impor pada maret 2015 mencatat impor gandum mencapai 6,63\% atau 93,155 ton. Menurut Corinthian (2008) menyatakan bahwa produksi cake naik setiap tahun $3,4 \%$ pertahunnya dan pada tahun 2007 mencatat produksi cake mencapai 1,19 juta ton. Berdasarkan kebutuhan terigu dalam pembuatan cake sangat tinggi, salah satu upaya untuk mengurangi penggunaan terigu dibutuhkan diversifikasi pangan dengan substitusi tepung terigu dengan tepung dari komoditi lain seperti tepung labu kuning dan koro pedang.
Koro pedang (Canavalia ensiformis) merupakan jenis koro-koroan sebagai sumber protein nabati dan kandungan gizi yang cukup tinggi seperti karbohidrat 55 $\%$, dan protein $24 \%$ (Windrati et al., 2010). Menurut Subagio et al. (2003) menyatakan protein dari koro pedang mempunyai sifat penyerapan dan pengikatan air yang tinggi, mempunyai kemampuan sebagai pengemulsi dan pembantukan busa, sehingga dapat meningkatkan mutu cake. Jumlah produksi koro pedang pada tahun 2016 mencapai 12 ton/ha menurut Litbang Pangan dan Pertanian (2016) sehingga dapat digunakan untuk mengurangi penggunaan terigu dalam pembuatan cake

Labu kuning (Cucurbita moschata Durch) merupakan salah satu komoditas pertanian yang memiliki memiliki kandungan protein sebesar $1,1 \%$ dan 
karbohidrat $6,6 \%$ dengan jumlah produksi labu kuning menurut departemen pertanian 2012 di jawa timur tahun 2011 mencapai $24,2 \%$ atau 42,197 ton (Sudarto,2000). Substitusi tepung labu kuning dan tepung koro pedang diharapkan bisa digunakan sebagai bahan pembuatan cake, serta dapat meningkatkan sifat organoleptik yang akan mempengaruhi daya terima di masyarakat. Oleh karena itu dilakukan penelitian ini untuk mengetahui pengaruh penggunaan tepung labu kuning dan tepung koro pedang terhadap karakteristik fisik dan organoleptik cake, untuk mengetahui formulasi penggunaan tepung labu kuning dan tepung koro pedang yang tepat sehingga dihasilkan cake dengan karakteristik fisik, kimia yang baik dan disukai.

\section{METODE PENELITIAN}

\section{Alat dan Bahan}

Alat yang digunakan pada pembuatan tepung labu kuning, tepung koro pedang dan cake adalah pisau, kompor, gas, saringan, ayakan, dandang, pasrahan, blander (Philips), panci, oven, loyang, mixer, neraca analitik (Ohaus, USA), sendok, wadah, solet. Peralatan yang digunakan untuk analisis adalah peralatan gelas (glassware), colourreader (CR-10 Minolta, Japan), oven (Selecta), loyang, kurs porselen, tanur pengabuan (merek Naberthem), penjepit cawan, spatula, labu khejdahl Buchi, kamera, soxhlet, destilator Buchi K-355, pnetrometer, mortar dan alu.

Bahan yang digunakan dalam penelitian ini labu kuning (Cucurbita moschata Durch) diperoleh dari pasar Situbondo kabupaten Situbondo, koro pedang (Canavalia ensiformis) diperoleh dari kecamatan Cerme kabupaten Bondowoso, terigu segitiga biru dengan kandungan protein sedang, gula halus, telur, margarin, ovalet, kertas kue, air. Bahan kimia yang digunakan $\mathrm{HCl}, \mathrm{NaOH}$, $\mathrm{H}_{2} \mathrm{SO}_{4}$, aquades, asam borat, selenium, metil blue, benzene, kertas saring dan alumunium foil.

\section{Tahapan Penelitian}

Pembuatan tepung labu kuning

Menurut Hendrasty (2003), pertama melakukan pengupasan kulit, memisahkan jonjot dan daging buahnya. Kemudian daging buah dibersihkan hingga bersih dan dilakukan pengecilan ukuran hingga ukuran $\pm 2 \mathrm{~mm}$. Kemudian pengeringan dilakukan dua kali, pengeringan menggunakan sinar matahari selama 2 jam dilakukan untuk mengurangi kandungan air yang terdapat dalam labu kuning,selanjutnya pengeringan oven pada suhu $60^{\circ} \mathrm{C}$ selama 24 jam, pengeringan bertujuan untuk mengurangi kadar air yang terdapat dalam labu kuning. Selanjunya dilakukan pengalusan menggunakan blander, penghalusan ini bertujuan untuk mengecilkan ukuran, kemudian dilakukan pengayakan 80 mesh, pengayakan ini bertujuan untuk menyeragamkan ukuran sehingga hampir sama dengan tepung.

\section{Pembuatan tepung koro pedang}

Pembuatan tepung koro pedang sesuai dengan cara Nafi' et al. (2015). Pencucian koro pedang dilakukan untuk menghilangkan kotoran yang ada pada koro pedang. Kemudian perendaman selama 48 jam dengan penggantian air setiap 6 jam, perendaman ini dilakukan untuk menghikangkan $\mathrm{HCN}$ yang terdapat pada koro pedang. Selanjutnya dilakukan perebuasan selama 1 jam dengan wadah terbuka agar sisa-sisa $\mathrm{HCN}$ yang terdapat pada koro pedang dapan keluar bersama dengan uap, selanjutnya dicuci dan tiriskan. Dilakukan pengupasan dan penirisan selanjutnya dilakukan pengeringan. Proses pengeringan dilakukan pada suhu $60^{\circ} \mathrm{C}$ selama 24 jam. Kemudian dilakukan penepungan dengan pengalusan menggunakan blander, kemudian dilakukan pengayakan 80 mesh, pengayakan ini bertujuan untuk 
menyeragamkan ukuran sehingga hampir sama dengan tepung.

\section{Pembuatan cake}

Pembuatan cake dengan menyiapkan telur, gula, ovalet, kemudian dilakukan pengocokan menggunakan mixer dengan kecepatan tinggi selama 10-15 menit sehingga dicapai kondisi berwarna putih dan mengembang. Seletah adonan mengembang dilakukan pencampuran tepung sesuai dengan formulasi dan menggunakan kecepatan sedang, saat adonan telah tercampur rata masukkan margarine yang telah dicairkan dengan kecepatan rendah pengadukan dilakukan untuk menghomogenkan adonan. Selanjutnya dimasukkan kedalam loyang yang telah di olesi margarin kemudian dilakukan pengovenan pada suhu $160^{\circ} \mathrm{C} 45$ menit, pengovenan ini bertujuan untuk mematangkan adonan hingga menjadi cake.

\section{Rancangan Percobaan}

Parameter yang diuji pada penelitian ini adalah uji organoleptik (warna, aroma, rasa, tekstur dan keseluruhan), uji fisik (warna, kenampakan irisan, daya kembang, staleness). Uji kimia (kadar air, kadar abu, kadar lemak, kadar protein dan kadar karbohidrat). Data yang diperoleh pada data uji organoleptik dianalisa menggunakan uji Friedmen, untuk uji fisik dianalisa menggunakan sidik ragam (ANOVA) dan jika terdapat perbedaan dilanjutkan dengan menggunakan uji Duncan New Multiple Range Test (DNMRT) pada taraf uji $\alpha \leq 5 \%$, sedangkan uji kimia menggunakan deskriptif. Penentuan perlakuan terbaik ditentukan berdasarkan hasil analisis uji fisik dan penerimaan panelis menggunakan uji efektifitas.

\section{HASIL DAN PEMBAHASAN}

\section{Sifat Organoleptik Cake}

Warna

Hasil uji friedman menunjukkan bahwa substitusi tepung labu kuning dan tepung koro pedang berpengaruh nyata terhadap kesukaan warna cake. Uji kesukaan warna cake dapat dilihat pada

\section{Gambar 1.}

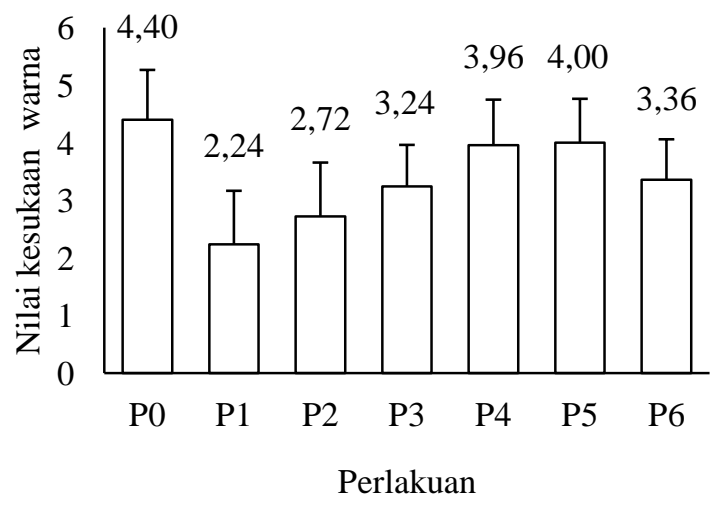

Gambar 1. Nilai kesukaan warna cake

Nilai kesukaan warna cake tertinggi terdapat pada perlakuan P0 sebesar 4,4 sedangkan nilai kesukaan warna terendah sebesar 2,24 pada P1. Warna cake P0 lebih disukai panelis dikarenakan memiliki warna putih kekuningan dibandingkan cake P1 yang memiliki warna lebih coklat. Menurut See et al. (2007) menyatakan warna pada tepung labu kuning yang dominan berwarna kuning-jingga sehingga mempengaruhi warna produk akhir makanan. Intensitas warna cake yang dihasilkan dipengaruhi oleh tingkat formulasi tepung labu kuning yang digunakan, sehingga semakin banyak penggunaan tepung labu kuning maka warna cake akan semakin coklat.

Rasa

Hasil uji friedman menunjukkan bahwa substitusi tepung labu kuning dan tepung koro pedang berpengaruh nyata terhadap kesukaan rasa cake. Uji kesukaan rasa cake dapat dilihat pada Gambar 2. Nilai kesukaan rasa cake tertinggi terdapat 
pada perlakuan $\mathrm{P} 0$ sebesar 4,44 sedangkan nilai kesukaan rasa terendah sebesar 3,28 pada P1. Rasa cake P0 lebih disukai panelis dikarenakan panelis masih terbiasa dengan rasa cake yang terbuat dari terigu dibandingkan rasa cake $\mathrm{P} 1$, hal ini dikarenakan penambahan tepung labu kuning tertinggi terdapat pada cake dengan formulasi P1.

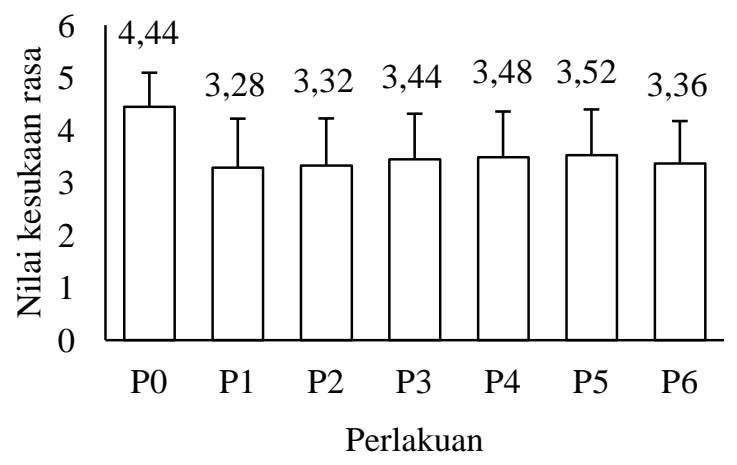

Gambar 2. Nilai kesukaan rasa cake

Menurut Kristianingsih (2010), semakin sedikit penambahan tepung labu kuning maka rasa cake yang dihasilkan manis dan gurih seimbang. Sebaliknya jika penambahan tepung labu kuning semakin banyak maka cake yang dihasilkan masih memiliki rasa manis yang ideal dan gurih akan tetapi cenderung terasa agak pahit.

\section{Aroma}

Hasil uji friedman menunjukkan bahwa substitusi tepung labu kuning dan tepung koro pedang berpengaruh tidak nyata terhadap kesukaan aroma cake. Uji kesukaan aroma cake dapat dilihat pada Gambar 3.

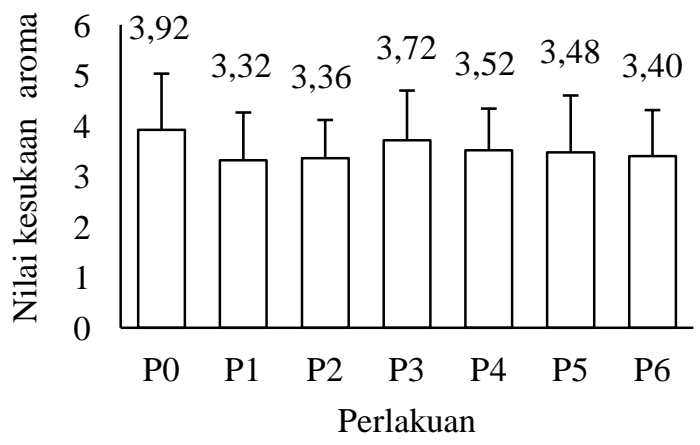

Gambar3. Nilai kesukaan aroma cake
Nilai kesukaan aroma cake tertinggi terdapat pada perlakuan P0 3,92 sedangkan nilai kesukaan aroma terendah sebesar 3,32 pada P1. Aroma cake P0 lebih disukai panelis dikarenakan panelis masih terbiasa dengan aroma cake yang terbuat dari terigu dibandingkan rasa cake $\mathrm{P} 1$, dikarenakan cake P1 memiliki penambahan tepung labu kuning lebih banyak. Aroma cake yang dihasilkan dipengaruhi oleh penambahan tepung labu kuning. Hendrasty (2003) menyatakan tepung labu kuning memiliki karakteristik aroma khas langu, sehingga panelis kurang menyukai cake yang memiliki penambahan tepung labu kuning lebih banyak.

\section{Tekstur}

Hasil uji friedman menunjukkan bahwa substitusi tepung labu kuning dan tepung koro pedang berpengaruh nyata terhadap kesukaan tekstur cake. Uji kesukaan tekatur cake dapat dilihat pada

\section{Gambar 4.}

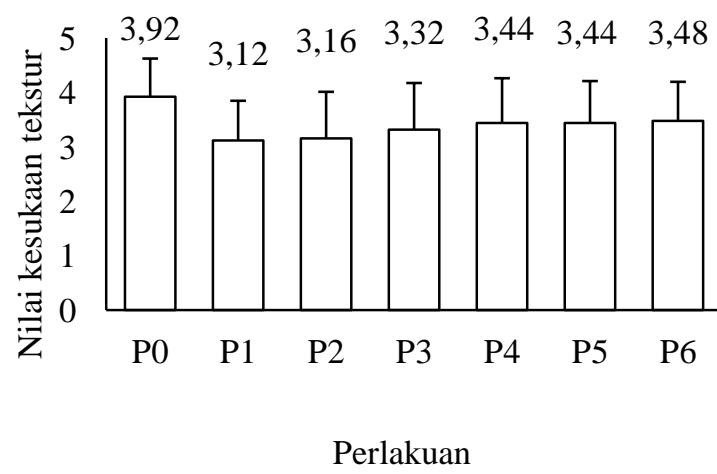

Gambar 4. Nilai kesukaan tekstur cake

Nilai kesukaan tekstur cake tertinggi terdapat pada perlakuan P0 sebesar 3,92 sedangkan nilai kesukaan tekstur terendah sebesar 3,12 pada P1. Tekstur cake P0 lebih disukai panelis dikarenakan tekstur cake $\mathrm{P} 0$ lebih lembut daripada P1, dikarenakan penambahan tepung labu kuning yang lebih banyak. tepung labu kuning memiliki sifat higroskopis sehingga mudah menyerap air yang membuat tepung sedikit menggupal. 
Menurut Imzalfida (2016), semakin halus tepung yang digunakan akan semakin halus tekstur cake. Semakin rendah jumlah penambahan tepung labu kuning cake yang dihasilkan akan semakin lembut.

\section{Keseluruhan}

Hasil uji friedman menunjukkan bahwa substitusi tepung labu kuning dan tepung koro pedang berperngaruh nyata terhadap penilaian keseluruhan cake. Uji kesukaan keseluruhan cake dapat dilihat pada Gambar 5.

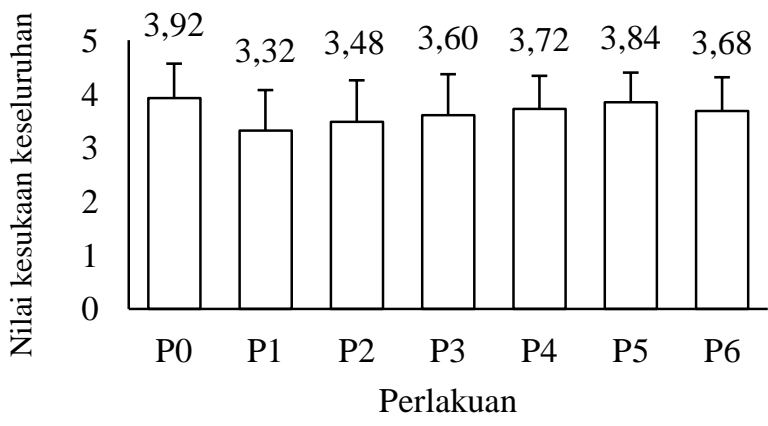

Gambar 5. Nilai kesukaan keseluruhan cake

Nilai kesukaan keseluruhan cake tertinggi terdapat pada perlakuan P0 sebesar 3,92 sedangkan nilai kesukaan keseluruhan terendah sebesar 3,32 pada P1. Secara keseluruhan panelis masih menyukai cake yang berbahan dasar $100 \%$ terigu, dikarenakan panelis masih terbiasa dengan cake pada umumnya. Nilai kesukaan tertinggi yang mendekati P0 ada pada perlakuan P5. Berdasarkan hasil uji organoleptik cake yang dapat diterima oleh panelis adalah cake dengan perlakuan $\mathrm{P} 0$ dan P5.

\section{Sifat Fisik Cake}

Warna (Chroma)

Hasil sidik ragam taraf 5\% dapat diketahui bahwa substitusi tepung labu kuning dan koro pedang berpengaruh nyata terhadap chroma cake yang dihasilkan. Hasil pengamatan chroma dapat dilihat pada Gambar 6.

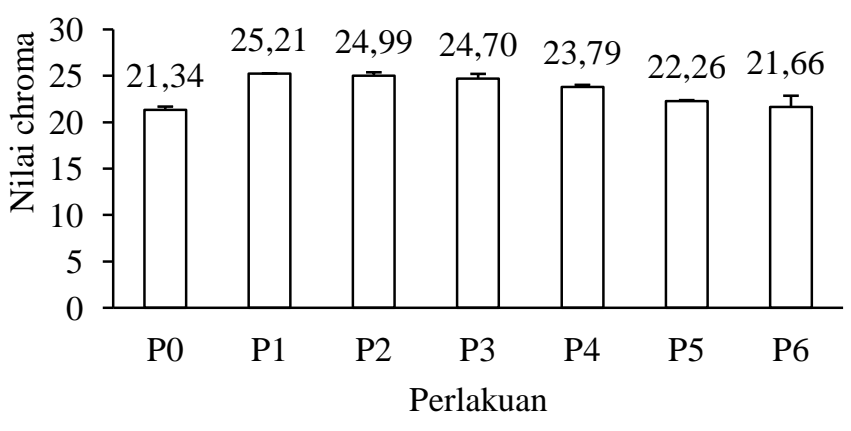

Gambar 6. Nilai chroma cake

Menurut Hardiyanti et al. (2005) chroma adalah intensitas warna dari suatu produk atau bahan makanan. Semakin tinggi intensitas warna (chroma) semakin pekat. Perlakuan P1 memiliki nilai tertinggi sebesar 25,21 yang menunjukkan cake lebih pekat daripada pelakuan lain. Hal ini dikarenakan penambahan tepung labu kuning yang lebih banyak sehingga membuat cake menjadi lebih pekat. Sedangkan nilai chroma terendah 21,34 terdapat pada pelakuan $\mathrm{P} 0$.

\section{Warna (hue)}

Hasil sidik ragam taraf $5 \%$ dapat diketahui bahwa substitusi tepung labu kuning dan koro pedang berpengaruh nyata terhadap warna cake yang dihasilkan. Hasil pengamatan hue dapat dilihat pada Gambar 7.

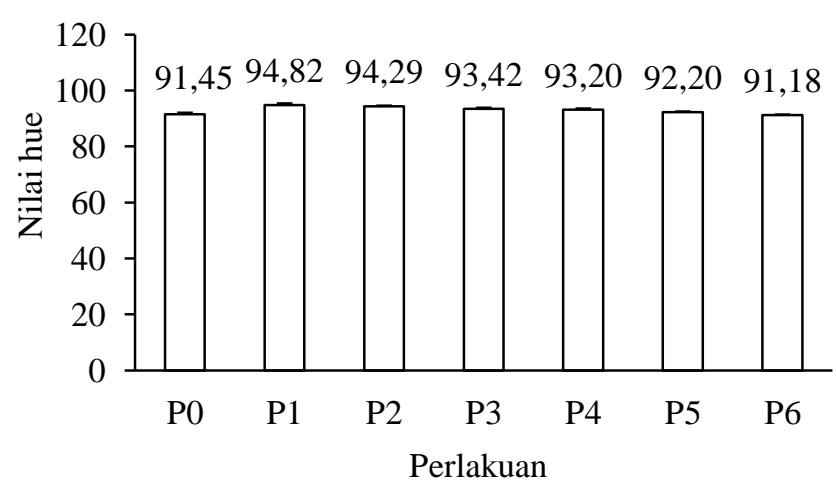

Gambar 7. Nilai hue Cake

Menurut hutching (1999) range sudut hue antara 90-126 menunjukkan deskripsi warna terdapat pada range kuning. Semakin besar nilai (hue) maka 
warna akan semakin kuning pekat. Perbedaan warna cake disebabkan karena formulasi penambahan tepung labu kuning yang berbeda. Pada perlakuan P0 memiliki nilai 91,45 dengan warna putih kekuningan sedangkan pada perlakuan P6 memiliki warna yang hampir sama dengan kontrol sebesar 91,18 dibandingkan dengan perlakuan lain. Cake yang dihasilkan lebih putih kenuningan dikarenakan pada perlakuan P6 tanpa penambahan tepung labu kuning dan tepung koro pedang memiliki warna tepung putih dibandingkan tepung labu kuning. Menurut Gilang et al. (2013) tepung koro pedang memiliki derajat putih 85,05 yang mendekati terigu 86,5 . Hal ini yang menyebabkan warna cake menjadi putih kekuningan.

\section{Kenampakan irisan}

Kenampakan irisan dilakukan dengan memotret hasil irisan dari cake dan diamati kenampakan pori-pori cake. Irisan cake yang baik memiliki pori-pori halus, seragam, merata, dam nampak kecil-kecil. Kenampakan irisan cake dapat dilihat pada Gambar 8. Berdasarkan hasil penelitian untuk kenampakan irisan cake memiliki rongga-rongga yang hampir sama.

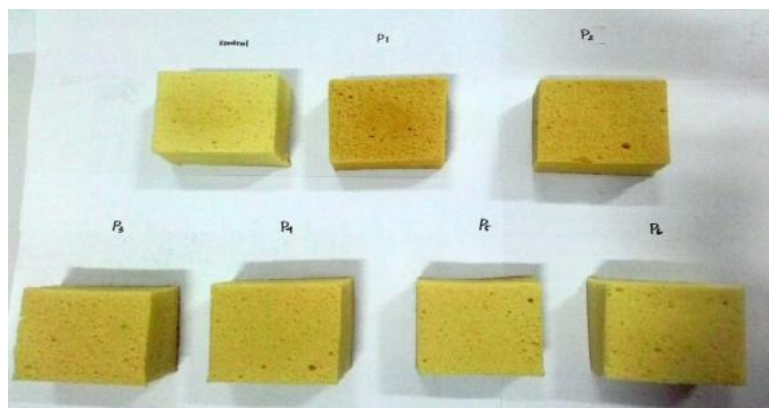

Gambar 8. Nilai kenampakan irisan cake

Kenampakan irisan cake terkait dengan bahan dan proses pencampuran. Perlakuan P0 memiliki kenampakan poripori yang seragam, dibandingkan dengan perlakuan yang lain. Dilihat dari kenampakannya perlakuan P1 memiliki pori-pori yang kurang rata dan besar, dikarenakan tepung labu kuning memiliki sifat higroskopis sehingga mudah menyerap air dan membuat tepung sedikit menggupal. Semakin banyak penambahan tepung koro pedang cake yang dihasilkan memiliki pori-pori yang lebih seragam.

\section{Daya kembang}

Hasil sidik ragam taraf 5\% dapat diketahui bahwa substitusi tepung labu kuning dan koro pedang berpengaruh nyata terhadap daya kembang cake yang dihasilkan. Hasil pengamatan daya kembang dapat dilihat pada Gambar 9.

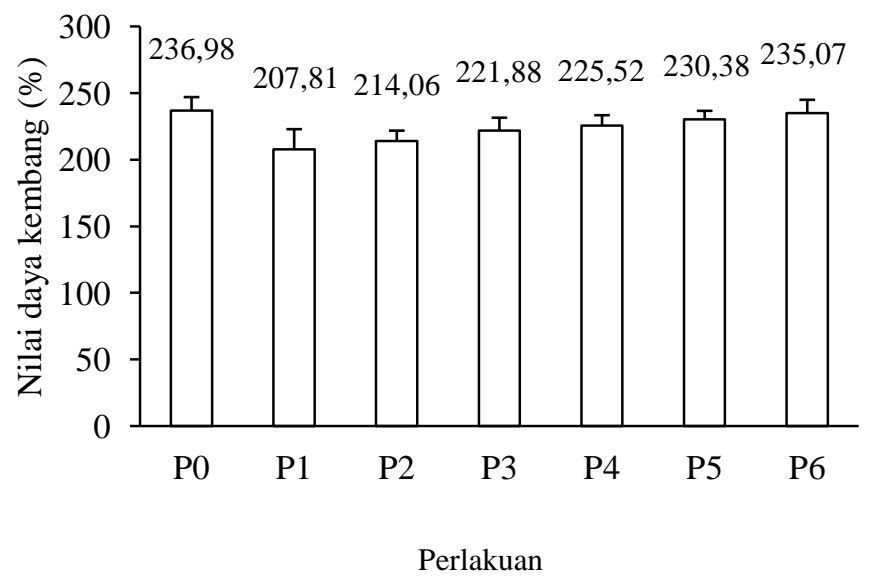

Gambar 9. Nilai daya kembang cake

Nilai daya kembang yang tinggi ada pada perlakuan P0 dengan nilai sebesar 236,98 dan terendah ada pada P1 sebesar 207,81. Daya kembang cake yang mendekati P0 adalah pada perlakuan P6 sebesar 235,07. Semakin banyak penggunaan tepung koro pedang cake yang dihasilkan semakin mengembang, hal ini dikarenakan protein dari koro pedang mempunyai sifat menyerap dan mengikat air yang tinggi, mempunyai kemampuan sebagai pengemulsi dan pembentukan busa (Subagio et al., 2003).

\section{Staleness Cake}

Hasil sidik ragam taraf $5 \%$ dapat diketahui bahwa substitusi tepung labu kuning dan koro pedang berpengaruh tidak nyata terhadap tekstur cake yang 
dihasilkan. Hasil penelitian yang dilakukan pengukuran tekstur pada hari ke-0 dapat dilihat pada Gambar 10. $\Delta$ perubahan tekstur cake selama penyimpanan pada hari ke-0 hingga hari ke-2 dapat dilihat pada Gambar 11.

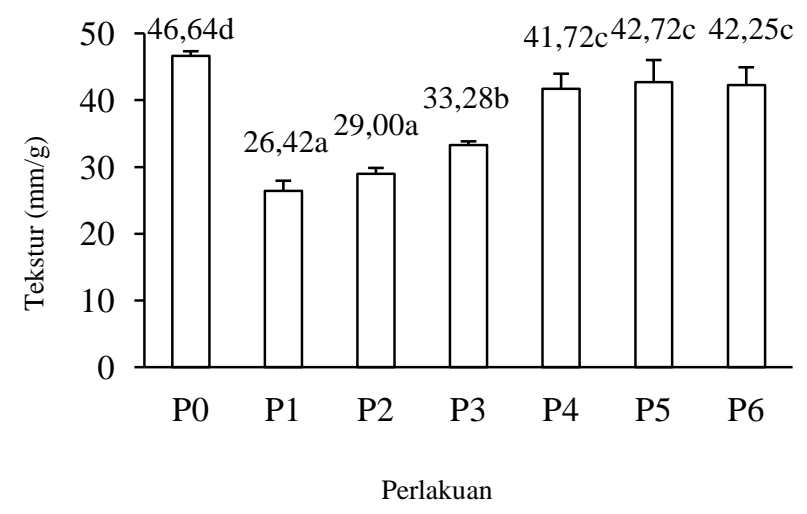

Gambar 10. Nilai tekstur cake pada hari ke-0 (H0)

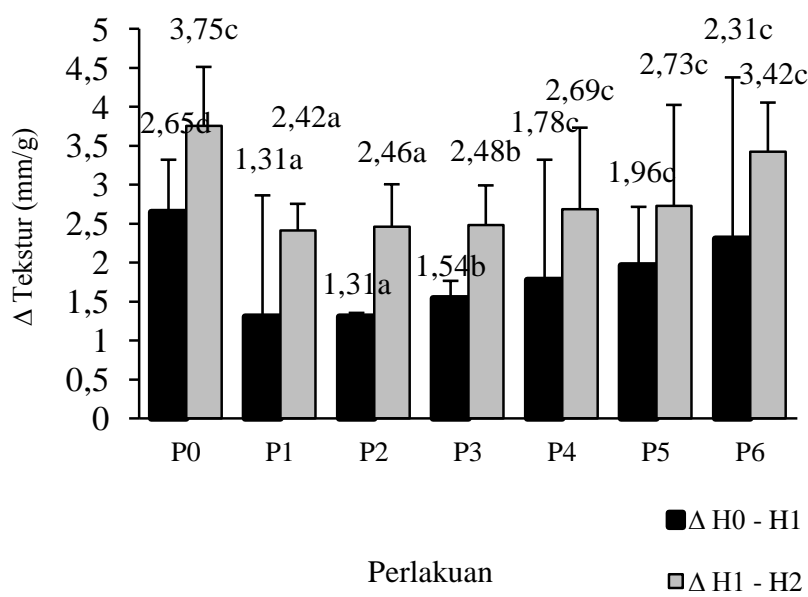

Gambar 11. $\Delta$ Perubahan tekstur cake selama penyimpanan pada hari ke-0 hingga hari ke-2

Selama penyimpanan dari hari ke-0 hingga hari ke-2 nilai tekstur mengalami penurunan, hal ini menandakan bahwa cake memiliki tekstur semakin keras. Pengerasan pada tekstur cake sering terjadi selama penyimpanan. Hal ini dikarenakan adanya peristiwa retrogradasi pati yang menyebabkan kehilangan sejumlah air pada cake (Verdagustiana, 2008). $\Delta$ perubahan semakin kecil menunjukkan bahan yang digunakan baik untuk pembuatan produk tersebut. Dari pengamatan penyimpanan yang telah dilakukan semakin banyak penambahan koro pedang $\Delta$ perubahan tekstur semakin besar. Hal ini dikarenakan kandungan amilosa koro pedang lebih tinggi dari pada labu kuning. Semakin besar kandungan amilosa peristiwa retrogradasi semakin mudah terjadi.

\section{Uji Efektivitas}

Berdasarkan hasil uji organoleptik dan uji fisik cake, dilakukan uji efektivitas untuk mendapatkan 2 formulasi terbaik. Uji efektivitas cake dapat dilihat pada Gambar 12. Berdasarkan hasil uji efektivitas dapat diketahui formulasi terbaik pada pembuatan cake ada pada perlakuan P4 (50\% terigu : $20 \%$ tepung labu kuning : 30\% tepung koro pedang) dan P5 (50\% terigu : $10 \%$ tepung labu kuning : $40 \%$ tepung koro pedang).

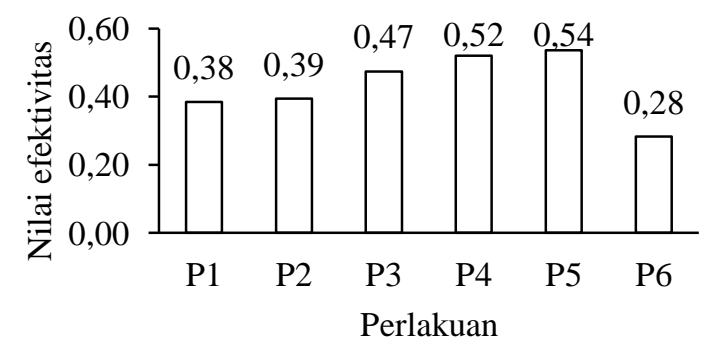

Gambar 12. Nilai efektivitas cake

\section{Sifat Kimia Cake}

Kadar air

Kadar air cake berkisar antara $37,81 \%$ - 38,34\% (Gambar 13). Berdasarkan hasil uji kadar air menunjukkan pada perlakuan P0 $(100 \%$ terigu) memiliki kadar air sebesar $37,81 \%$, perlakuan $\mathrm{P} 4$ (50\% terigu : $20 \%$ tepung labu kuning : 30\% tepung koro pedang) memiliki kadar air 38,34\% dan perlakuan P5 (50\% terigu : $10 \%$ tepung labu kuning : $40 \%$ tepung koro pedang) memiliki kadar air 38,26\%. Semakin banyak penambahan tepung labu kuning maka kadar air cake semakin tinggi, hal ini dikarenakan labu kuning mengandung pektin yang mampu mengikat air lebih baik daripada pati 
dalam tepung terigu. Meski labu kuning sudah dijadikan tepung namun pektin dalam labu kuning tidak rusak bahkan dapat mengikat air dengan baik (Saragih, 2007).

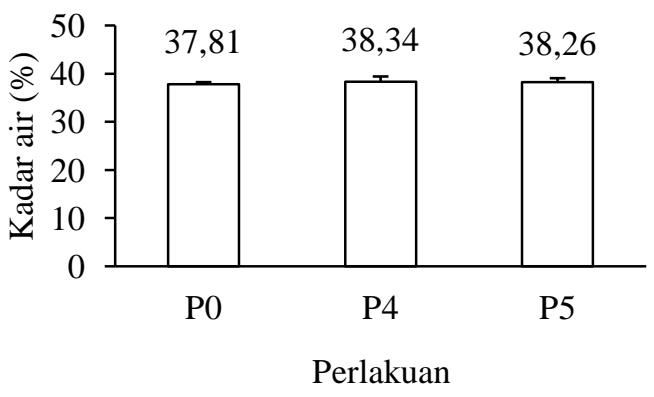

Gambar 13. Kadar air cake

\section{Kadar abu}

Kadar abu cake berkisar antara $0,62 \%$ - 0,96\% (Gambar 14). Berdasarkan hasil uji kadar abu menunjukkan pada perlakuan P0 (100\% terigu) memiliki kadar abu sebesar 0,96\%, perlakuan $\mathrm{P} 4$ (50\% terigu : $20 \%$ tepung labu kuning : $30 \%$ tepung koro pedang) memiliki kadar abu $0,85 \%$ dan perlakuan P5 (50\% terigu : 10\% tepung labu kuning : $40 \%$ tepung koro pedang) memiliki kadar abu 0,96\%. Semakin banyak penambahan tepung koro pedang kadar abu semakin tinggi, hal ini diduga karena kandungan mineral pada tepung koro pedang lebih tinggi dibandingkan pada terigu.

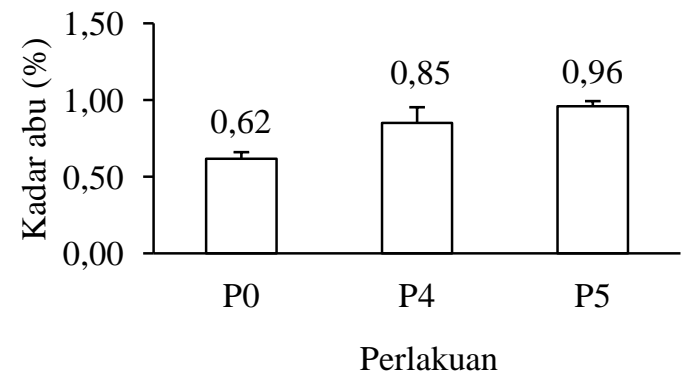

Gambar 14. Kadar abu cake

\section{Kadar lemak}

Kadar lemak cake berkisar antara 2,99\% - 4,01\% (Gambar 15). Berdasarkan hasil uji kadar lemak menunjukkan pada perlakuan P0 (100\% terigu) memiliki kadar lemak sebesar 2,99\%, perlakuan P4 (50\% terigu : $20 \%$ tepung labu kuning : $30 \%$ tepung koro pedang) memiliki kadar lemak 3,94\% dan perlakuan P5 $(50 \%$ terigu : $10 \%$ tepung labu kuning : $40 \%$ tepung koro pedang) memiliki kadar lemak $4,01 \%$. Semakin banyak penambahan tepung koro pedang kadar lemak semakin tinggi. Menurut Subagio et al. (2002) kandungan lemak biji koro pedang yaitu sebesar 4,0\%, sedangkan kandungan lemak terigu 1,3\% (Departemen Kesehatan Republik Indonesia, 1996).

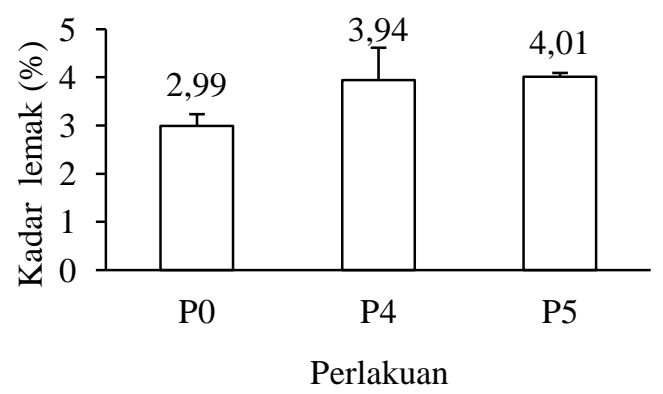

Gambar 15. Kadar lemak cake

Kadar Protein

Kadar protein cake berkisar antara $15,29 \%$ - 28,28\% (Gambar 16). Berdasarkan hasil uji kadar protein menunjukkan pada perlakuan P0 $(100 \%$ terigu) memiliki kadar protein sebesar $15,29 \%$, perlakuan P4 (50\%terigu : 20\%tepung labu kuning : $30 \%$ tepung koro pedang) memiliki kadar protein 25,82\% dan perlakuan P5 (50\%terigu : 10\%tepung labu kuning : $40 \%$ tepung koro pedang) memiliki kadar protein 28,28\%. Semakin banyak penambahan tepung koro pedang kadar protein semakin tinggi, hal ini diduga karena koro pedang memiliki kandungan protein yang cukup tinggi sebesar 24\% (Windrati et al., 2010). 


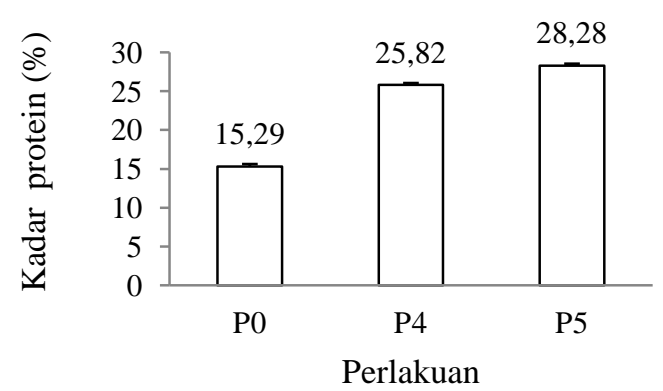

Gambar 16. Kadar Protein cake

\section{Kadar Karbohidrat}

Kadar karbohidrat cake berkisar antara 31,47\% - 46,99\% (Gambar 17). Berdasarkan hasil uji kadar karbohidrat menunjukkan pada perlakuan P0 (100\% terigu) memiliki kadar karbohidrat sebesar 46,99\%, perlakuan P4 (50\%terigu : 20\% tepung labu kuning : $30 \%$ tepung koro pedang) memiliki kadar karbohidrat $33,83 \%$ dan perlakuan P5 (50\%terigu : 10\%tepung labu kuning : $40 \%$ tepung koro pedang) memiliki kadar karbohidrat $31,47 \%$. Semakin banyak penambahan tepung labu kuning kadar karbohidrat semakin tinggi, hal ini diduga karena kandungan karbohidrat tepung labu kuning sebesar 77,6\% (Iriani,2011).

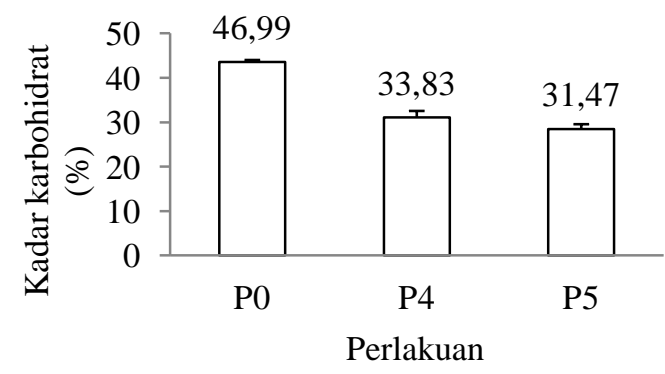

Gambar 17. Kadar Karbohidrat cake

\section{KESIMPULAN}

Formulasi penggunaan tepung labu kuning dan koro pedang terhadap terigu pada pembuatan cake berpengaruh nyata terhadap kesukaan warna, rasa, tekstur, keseluruhan, warna (hue dan chroma), daya kembang, staleness, kadar abu, kadar lemak, kadar protein dan kadar karbohidrat, tetapi berpengaruh tidak nyata terhadap aroma, dan kadar air. Formulasi yang terbaik pada pembuatan cake adalah P5 (50\% terigu: 10\%tepung labu kuning : $40 \%$ tepung koro pedang).

\section{UCAPAN TERIMAKASIH}

Ucapan terimakasih ditujukan kepada Ahmad Nafi',S.TP, M.P selaku dosen pembimbing utama dan Ir. Wiwik Siti Windrati, M.P selaku dosen pembimbing anggota. Dr. Ir. Herlina, M.P dan Ir. Noer Novijanto,M. App. Sc selaku tim penguji. Keluarga dan teman-teman yang mendoakan dan memdukung penelitian ini.

\section{DAFTAR PUSTAKA}

Badan Penelitian dan Pengembangan Pertanian. 2016. Rencana strategis badan penelitian dan pengembangan pertanian

(http://pangan.litbang.pertanian.go.id/be rita-725-kacang-potensial-pengganti-

kedelai-koro-pedang.html) [Diakses tanggal 15 April 2015].

Badan Pusat Statistik Kabupaten Jember. 2015. Berita resmi statistik No. 28/04/th.XIII.

(http://jatim.bps.go.id/index.php/Brs) Serial Online [Diakses tanggal 15 April 2015].

Chorinthian. 2008. Studi Tentang Industri dan Pemasaran Tepung Terigu di Indonesia. PT. Cirinthian Infopharma Corpora, Jakarta.

Departemen Kesehatan Republik Indonesia. 1996. Daftar Komposisi Bahan Makanan. Bhatara Karya Aksara. Jakarta.

Nafi'. A., Diniyah, N., dan Febriani, T. 2015. Karakteristik fisikokimia dan fungsional teknis tepung koro kratok (Phaseolus lunatus L.) termodifikasi yang diproduksi secara fermentasi spontan. Agrointek, 9 (1): 24-32.

Hendrasty, H.K. 2003. Tepung Labu Kuning Pembuatan dan Pemanfaatannya. Kanisius, Yogyakarta. 
Iriani, Vanti Rippi. 2011. "Pembuatan dan Analisis Kandungan Gizi Tepung Labu Kuning". Skripsi. Fakultas Teknologi Industri. Universitas Pembangunan Nasional 'Veteran' Jawa Timur, Surabaya.

Imzalfida, M. 2016. Pengaruh substitusi tepung gembili (Dioscorea esculenta Linn.) terhadap sifat organoleptik chiffon cake. e-Journal Boga, 5 (1): $54-$ 62 .

Kristianingsih, Z. 2010. “Pengaruh Substitusi Labu Kuning Terhadap Kualitas Brownies Kukus" . Skripsi. Universitas Negeri Semarang.

Saragih, B., O. Ferry, dan Sanoya, A. 2007. Kajian Pemanfaatan Tepung Bonggol Pisang (Musa paradisiaca Linn) sebagai Substitusi Tepung Terigu. Dalam Pembuatan Mie Basah. Universitas Mulawarman, Samarinda.

See, E. F., Wan, N. W. A., dan Noor A. A. A., 2007. Physico-chemical and sensory evaluation of breads supplemented with pumpkin flour. ASEAN Food Journal, 14 (2) : 123-130.

Subagio, A., Windarti,W.S., dan Witono, Y. 2003. Pengaruh Penambahan Isolat Protein Koro Pedang (Canavalia ensiformis L.) terhadap karakteristik cake. Jurnal Teknologi dan Industri Pangan, 14 (2): 136-143.

Subagio, A., Witono, Y., dan Wiwik, S.W. 2002. Protein albumin dan globumin dari beberapa jenis koro-koroan di indonesia. Prosiding Seminar Nasional PATPI Kelompok Gizi dan Keamanan Pangan, pp: 143-151.

Sudarto, Y. 2000. Budidaya Wuluh. Kanisius, Yogyakarta.

Verdagustiana. I. 2008. Aplikasi Produk Interaksi Antara Protein Koro Pedang (Canacalia ensiformis L) dan Gum Xanthan Dengan Penambahan Dextrin Pada Pembuatan Cake. Fakultas Teknologi Pertanian. Universitas Jember.
Windrati, W. S., Nafi', A., dan Augustine, P. D. 2010. Sifat Nutrisional protein rich flour (PRF) koro pedang (Canavalia ensiformis L.). Jurnal Agrotek, 4 (1): 18-26. 